\title{
Prevalence of Human Immunodeficiency Virus Infection among Tuberculosis Patients in Nepal
}

\author{
Nilaramba Adhikari, ${ }^{1}$ Ratna Bhattarai, ${ }^{1}$ Rajendra Basnet, ${ }^{1}$ Bhim Singh Tinkari, ${ }^{2}$ Badri Nath Gyawali, ${ }^{2}$ Lok Raj \\ Joshi $^{1}$ \\ ${ }^{1}$ National Tuberculosis Center/Global Fund Program, Bhaktapur, Nepal. ${ }^{2}$ National Tuberculosis Center, Bhaktapur, \\ Nepal.
}

\section{ABSTRACT}

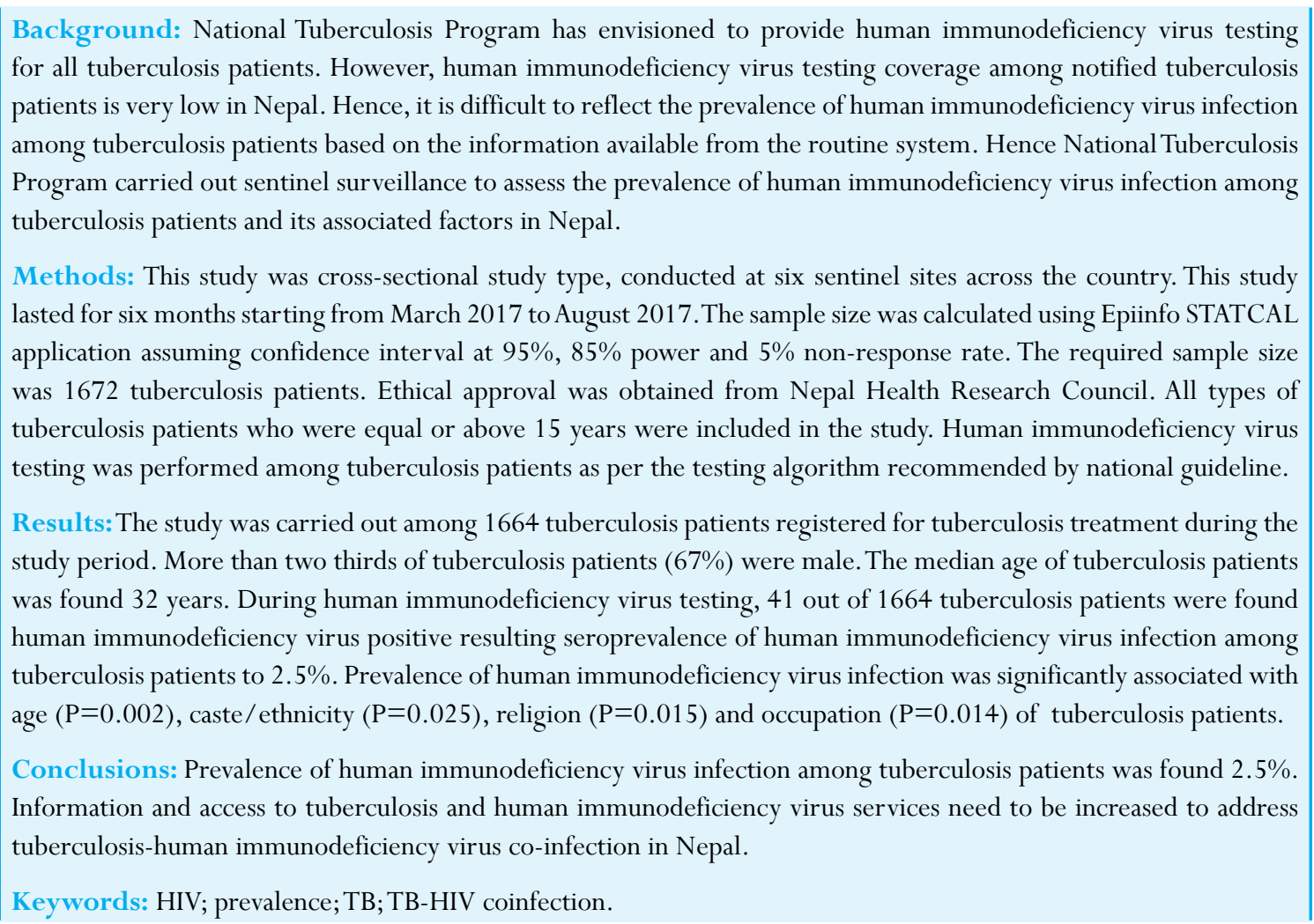

\section{INTRODUCTION}

World Health Organization (WHO) estimated around 45,000 new tuberculosis (TB) cases in Nepal in 2016. ${ }^{1}$ However only 32,056 cases equivalent to $71 \%$ of estimated TB cases were notified by the National Tuberculosis Program (NTP). ${ }^{2}$ Finding missing TB cases have been a major challenge for NTP. Meanwhile, concentrated epidemics of human immunodeficiency virus (HIV) in Nepal have augmented the risk of tuberculosis. TB and HIV co-infection is the leading cause of mortality among TB patients and people living with Human Immunodeficiency Virus (PLHIVs). Moreover,the prevalence of HIV among TB patients also indicates the spread of HIV into the general population. Despite the provision of HIV testing for all TB patients, routine information system shows very limited coverage of HIV testing among TB patients in Nepal. ${ }^{2}$ Hence, based on the available information, it is difficult to reflect its actual burden. Hence, NTP carried out sentinel surveillance at various DOTS Center to assess the prevalence of HIV among TB patients in Nepal.

Correspondence: Nilaramba Adhikari, National Tuberculosis Center/Global Fund Program, Thimi, Bhaktapur, Nepal. Email: nilaramba4u@gmail.com, Phone:+9779841000432. 


\section{METHODS}

A cross-sectional study design was adopted for this sentinel sero-prevalence survey. The survey was conducted at six sentinel sites namely Mahakali Zonal Hospital, Kanchapur, Western Regional Tuberculosis Center (WRTC), Kaski, National Anti-tuberculosis Association (NATA), Morang, United Mission Nepal (UMN), Palpa, National Tuberculosis Center (NTC), Bhaktapur and TB Nepal, Banke. These sites were selected based on the number of TB patients registered for anti-tuberculosis therapy (ATT). These treatment centers, with high caseload of TB patients, were assumed to have greater population coverage representing all geographical regions and socio-demographic characteristics like caste, ethnicity, religion and culture. Under NTP, these sites have been serving as a referral treatment centers providing advanced TB treatment and care services. This study continued for six months starting from March 2017 to August 2017.

The sample size was calculated by using Epi-info STATCAL application assuming a two-sided confidence level at $95 \%, 80 \%$ power (1-B) of the study. The proportion of HIV among TB patients was assumed to be $1.1 \%$, based on the finding from the similar sentinel surveillance conducted by NTP on fiscal year 2013/14. ${ }^{3}$ The required sample size for the study to monitor the trend of HIV prevalence among TB patients came to be 1,672 TB patients assuming $5 \%$ non-response rate. The number of samples from each sentinel sites were selected proportionately considering TB caseloads at respective sites. Consecutive sampling method was used; every patient who meets the eligibility criteria at the particular site was included in the study until the required sample size was reached. Based on the objectives of the study, a structured questionnaire was prepared and finalized by Technical Working Group (TWG) for the sentinel survey comprised of HIV, TB and Laboratory specialists. Statistical Package for Social Science (SPSS version 20) was used for analysis.

Ethical approval for this survey was obtained from Nepal Health Research Council (NHRC). All types of TB patients (smear positive, smear negative, extra-pulmonary) who are equal or above 15 years of age at the time of TB treatment at selected sentinel sites were eligible to take part in the study. TB patients not meeting above inclusion criterions were excluded from the sampling frame. However their right to know the serological status was protected through counselling and referring them to appropriate treatment and testing site. Informed consent, both verbal and written, from each eligible TB patient was obtained prior the participation in the survey. Similarly participants were informed about their voluntary participation in the survey as well as assured them their right to leave survey at any time for any reasons. All eligible respondents who gave their consent for the participation in the survey were counselled prior (pre-counselling) and after (Post-counselling) testing for HIV infection. Information obtained from all the eligible TB patients who went through the HIV testing were kept confidential and secured at the respective sentinel sites.

Health workers at treatment centers (Laboratory Technician, Survey Coordinator, Counselor) were provided one day orientation, prior the survey, to build their capacity for HIV testing as well as proper recording in the questionnaire. HIV testing was performed as per the testing algorithm recommended by national consolidated guidelines for treating and preventing HIV in Nepal 2014 for the diagnosis of HIV. ${ }^{4}$ The standard national strategy for HIV testing is based on the serial HIV testing algorithm using three different HIV test kits (Determine HIV $1 / 2$, Uni-Gold HIV and HIV $1 / 2$ Stat-Pak test kits). Similarly socio-demographic information of the TB patients was also collected through face-to-face interviews using a structured questionnaire. Collected information by health workers were reviewed by Provincial TB Coordinators for the possible errors. Once the information from the respondents was collected in sufficient number, data entry and analysis was assigned to third party to minimize possible biases. The data were entered directly into Statistical Package for Social Science (SPSS version 20) and were analysed for the statistical analysis. The association between sociodemographic characteristics with outcome variable i.e. HIV status were explored using bivariate logistic regression analysis. Value of $\mathrm{P}<0.05$ was considered significant where the confidence interval was set at $95 \%$ $(95 \% \mathrm{Cl})$.

\section{RESULTS}

The study was carried out among 1664 TB patients registered for the treatment at six sentinel sites during the study period (Table 1 ). Although the required sample size for the study was 1672 TB patients, 8 eligible TB patients didn't express their willingness to participate in the study. The overall acceptance rate among registered TB patients for HIV testing was $99.5 \%$. Among the total TB patients screened for HIV, 1242 (74.6\%) were Pulmonary TB, 422 (25.4\%) were extrapulmonary TB. During HIV testing, a total of 41 TB patients were found to be HIV positive resulting HIV seroprevalence among tuberculosis patients to $2.5 \%$. While prevalence of HIV among pulmonary TB cases was $2.8 \%$ and among extrapulmonary TB cases, it was $1.7 \%$ (Table 2 ). 


\begin{tabular}{|c|c|c|c|}
\hline $\begin{array}{l}\text { Sentinel } \\
\text { Sites }\end{array}$ & Location & Province & $\begin{array}{r}\text { Study } \\
\text { sample } \\
\text { size (\%) }\end{array}$ \\
\hline $\begin{array}{l}\text { Mahakali } \\
\text { Zonal } \\
\text { Hospital }\end{array}$ & $\begin{array}{l}\text { Mahendranagar, } \\
\text { Kanchanpur }\end{array}$ & $\begin{array}{l}\text { Sudurpaschim } \\
\text { Province }\end{array}$ & $\begin{array}{r}267 \\
(16.0)\end{array}$ \\
\hline $\begin{array}{l}\text { Regional } \\
\text { Tuberculosis } \\
\text { Center }\end{array}$ & Pokhara, Kaski & $\begin{array}{l}\text { Gandaki } \\
\text { Province }\end{array}$ & $\begin{array}{r}330 \\
(19.8)\end{array}$ \\
\hline $\begin{array}{l}\text { NATA- } \\
\text { Morang }\end{array}$ & $\begin{array}{l}\text { Biratnagar, } \\
\text { Morang }\end{array}$ & Province 1 & $\begin{array}{r}216 \\
(13.0)\end{array}$ \\
\hline $\begin{array}{l}\text { UMN } \\
\text { Hospital }\end{array}$ & Tansen, Palpa & Province 5 & $\begin{array}{r}177 \\
(10.6)\end{array}$ \\
\hline $\begin{array}{l}\text { National } \\
\text { Tuberculosis } \\
\text { Center }\end{array}$ & $\begin{array}{l}\text { Thimi, } \\
\text { Bhaktapur }\end{array}$ & Province 3 & $\begin{array}{r}498 \\
(29.9)\end{array}$ \\
\hline $\begin{array}{l}\text { TB Nepal- } \\
\text { Banke }\end{array}$ & $\begin{array}{l}\text { Nepalgunj, } \\
\text { Banke }\end{array}$ & Province 5 & $\begin{array}{r}176 \\
(10.6)\end{array}$ \\
\hline Total & & & $\begin{array}{r}1664 \\
(100.0)\end{array}$ \\
\hline
\end{tabular}

\begin{tabular}{|l|rrr|}
\hline Table 2. HIV co-infection among TB patients. \\
\hline Type of TB & $\begin{array}{r}\text { HIV Testing Result } \\
\text { Hegative }\end{array}$ & $\begin{array}{r}\text { HIV } \\
\text { Positive }\end{array}$ & $\begin{array}{r}\text { Total } \\
(\%)\end{array}$ \\
\hline Pulmonary TB & 1208 & 34 & 1242 \\
\hline Extrapulmonary TB & 415 & 7 & 422 \\
\hline Total (\%) & & & $(25.4 \%)$ \\
\hline
\end{tabular}

\begin{tabular}{|c|c|c|c|}
\hline \multirow[b]{2}{*}{ Sentinel Sites } & \multirow[b]{2}{*}{$\begin{array}{r}\text { Number } \\
\text { (n) }\end{array}$} & \multicolumn{2}{|c|}{ HIV Testing Result } \\
\hline & & $\begin{array}{r}\text { HIV } \\
\text { Negative } \\
(\%)\end{array}$ & $\begin{array}{r}\text { HIV } \\
\text { Positive } \\
(\%)\end{array}$ \\
\hline $\begin{array}{l}\text { Mahakali Zonal } \\
\text { Hospital, Kanchanpur }\end{array}$ & 267 & 99.6 & 0.4 \\
\hline $\begin{array}{l}\text { Regional Tuberculosis } \\
\text { Center, Kaski }\end{array}$ & 330 & 97.3 & 2.7 \\
\hline NATA-Morang & 216 & 95.4 & 4.6 \\
\hline UMN Hospital, Palpa & 177 & 93.8 & 6.2 \\
\hline $\begin{array}{l}\text { National Tuberculosis } \\
\text { Center, Bhaktapur }\end{array}$ & 498 & 98.6 & 1.4 \\
\hline TB Nepal- Banke & 176 & 98.3 & 1.7 \\
\hline Total (\%) & $\begin{array}{r}1664 \\
(100 \%)\end{array}$ & $\begin{array}{r}1623 \\
(97.5 \%)\end{array}$ & $\begin{array}{r}41 \\
(2.5 \%)\end{array}$ \\
\hline
\end{tabular}

Table 3 shows the detail information regarding the prevalence of HIV among TB patients at the selected sentinel sites. Table 4 demonstrates the sociodemographic characteristics of TB patients as well as their association with the prevalence of HIV. More than two third of TB patients $(67 \%)$ in the study were male. The median age of tuberculosis patients was 32 years with the range of (15-97) years. Majority of the respondents $(42 \%)$ belonged to age group category of (25-44) years. However, around 9.9\% (164) TB patients choosenot to disclose their age. Nearly two out of five TB patients were Janajatis (40\%), followed by Brahmin/ Chhetri (28\%), Dalits (20\%), Madhesi/Muslim (12\%) respectively.

\begin{tabular}{|c|c|c|c|c|}
\hline \multicolumn{5}{|c|}{$\begin{array}{l}\text { Table 4. Association between demographic } \\
\text { characteristics of TB patient and prevalence of HIV. }\end{array}$} \\
\hline \multirow{3}{*}{ Characteristics } & \multirow{3}{*}{$\begin{array}{l}\text { Number } \\
\text { (n) }\end{array}$} & \multicolumn{2}{|l|}{ HIV status } & \multirow{3}{*}{$P$ value } \\
\hline & & $\begin{array}{l}\text { Negative } \\
(\%)\end{array}$ & $\begin{array}{l}\text { Positive } \\
(\%)\end{array}$ & \\
\hline & & $n=1623$ & $\mathrm{n}=41$ & \\
\hline \multicolumn{5}{|l|}{ Age group ** } \\
\hline Less than 25 & 374 & 98.9 & 1.1 & \multirow{4}{*}{0.002} \\
\hline $25-44$ & 692 & 96.7 & 3.3 & \\
\hline 45 and above & 434 & 98.8 & 1.2 & \\
\hline $\begin{array}{l}\text { Age missing } \\
\text { (age not } \\
\text { disclosed) }\end{array}$ & 164 & 94.5 & 5.5 & \\
\hline \multicolumn{5}{|l|}{ Sex } \\
\hline Female & 548 & 97.6 & 2.4 & \multirow{2}{*}{0.0866} \\
\hline Male & 1116 & 97.5 & 2.5 & \\
\hline \multicolumn{5}{|l|}{ Caste/Ethnicity * } \\
\hline Dalit & 334 & 97.9 & 2.1 & \multirow{5}{*}{0.025} \\
\hline Janajati & 671 & 98.2 & 1.8 & \\
\hline $\begin{array}{l}\text { Madeshi/ } \\
\text { Muslim }\end{array}$ & 198 & 94.4 & 5.6 & \\
\hline $\begin{array}{l}\text { Brahmin/ } \\
\text { Chhetri/other }\end{array}$ & 461 & 97.6 & 2.4 & \\
\hline \multicolumn{4}{|l|}{ Religion * } & \\
\hline Hinduism & 1291 & 97.5 & 2.5 & \multirow{3}{*}{0.015} \\
\hline Buddhism & 280 & 98.9 & 1.1 & \\
\hline $\begin{array}{l}\text { Islam/ } \\
\text { Christian }\end{array}$ & 93 & 93.5 & 6.5 & \\
\hline \multicolumn{5}{|l|}{ Marital status } \\
\hline Ever married & 1267 & 97.3 & 2.7 & \multirow{2}{*}{0.302} \\
\hline Unmarried & 397 & 98.2 & 1.8 & \\
\hline Literacy status & & & & \\
\hline
\end{tabular}




\begin{tabular}{lllll}
\hline Illiterate & 1139 & 97.3 & 2.7 & 0.717 \\
Literate & 525 & 97.6 & 2.4 & \\
\cline { 1 - 1 } Occupation * & & & & \\
Agriculture & 649 & 98 & 2 & \\
\hline Labourer & 233 & 95.3 & 4.7 & \\
\hline Housewife & 236 & 95.8 & 4.2 & 0.014 \\
\hline Job & 133 & 98.2 & 1.8 & \\
\hline Others & 323 & 99.3 & 0.7 & \\
\hline
\end{tabular}

*Significant ${ }^{* *}$ Highly significant

This study found that prevalence of HIV among TB patients differed with different gender. Although the association wasn't statistically significant, male TB patients were more likely to have HIV-TB co-infection than female. Global trends have also shown that incident and mortality of TB occurs more in male than female..$^{1,13}$ Similarly for the developing countries like Nepal, where social structure prefers more male dominance than female, male are more involved in outdoor activities involving risky behaviors (like extramarital sexual activities, intravenous drug injection, alcohol consumption and smoking) which could have put them at increased risk for TB and HIV. Movement as well as

The prevalence of HIV among male TB patients $(2.5 \%)$ was found comparatively higher than among the female TB patients (2.4\%). However, the difference was not statistically significant $(P=0.866)$. Similarly, the prevalence of HIV was found significantly $(P<0.01)$ higher among the TB patients who choose not to disclose their age $(5.5 \%)$ than in TB patients belonging to (25$44)$ yearsage group (3.3\%) and was found lowest among less than 25 years TB patients (1.1\%). Prevalence of HIV was found significantly higher among Madhesi/Muslim TB patients $(5.6 \%, \mathrm{P}<0.05)$, among Christian/Islam TB patients $(6.5 \%, P<0.05)$ and among the labour $(4.7 \%$, $\mathrm{P}<0.05)$ respectively. Although the prevalence of HIV was found comparatively higher among married (2.7\%) and illiterate (2.7\%) TB patients, but the association was not found statistically significant.

\section{DISCUSSION}

Prevalence of HIV among TB patients was found 2.5\%. The prevalence has increased sharpely in comparison to the findings from the similar study conducted by NTC in 2013 (i.e. 1.1\%). ${ }^{3}$ However, it has increased slightly in comparision to the study conducted in 2011 (i.e. $2.4 \%$ ). ${ }^{5}$ Similar studies conducted in different neighbouring countries in Asia have found different results $10.5 \%$ in Guangxi, China, $1.0 \%$ to $13.8 \%$ in different districts of Eastern India, $0.34 \%$ in Sindh, Pakistan) which could be due to different socio-geographical, economic context as well different epidemics of HIV and TB..$^{6-8} \mathrm{It}$ was observed that the prevalence of HIV was found more prominent in pulmonary TB patients than extrapulmonary TB patients. In this study, pulmonary TB patients were 1.58 times more likely to have co-infection with HIV than extrapulmonary TB patients. Several other studies conducted in India and China have also found the similar association between TB classification types and HIV status. ${ }^{6,9,10}$ However, this finding contrasts with studies conducted in India and Pakistan which have shown higher prevalence of HIV infection among extrapulmonary TB cases. ${ }^{11,12}$ been the preferred destination among Nepalese migrants for earnings. Similarstudies conducted in Nepal, China have also found no any significant association between gender of TB patients and prevalence of HIV. ${ }^{5,6}$ However a study conducted in India found the association highly significant. ${ }^{8}$ This study found that the prevalence of HIV was significantly associated with the age of TB patients. The prevalence of HIV was 3.00 times higher among TB patients aged 25 to 44 years; 1.09 times higher among TB patients aged 45 years and above in comparison to the TB patients aged below 25 years. In this study, TB patients aged (24-44) years were the most affected age group. It could be due to high prevalence of TB and HIV among people belonging to (25-49) years age group. ${ }^{1,2,14}$ Howeverstudies conducted in China and Indiacouldn't detect any significant relationship between age of TB patients and prevalence of HIV. ${ }^{6,8}$ This study found that prevalence of HIV was significantly higher among the Madhesi/Muslim TB patients that TB patients belonging to other caste/ethnic groups (i.e. Brahmin/Chhetri, Dalit, Janajati). This could be due to fact that Madhesi/ Muslim population are largely concentrated acrossTerai region where the epidemic of TB and HIV ishigh. ${ }^{2,14}$ However, a study conducted in Guangxi China couldn't establish any significant association between caste/ ethnicity of TB patients and prevalence of HIV. ${ }^{6}$

This study found the significant relationship between prevalence of HIV and religion of the TB patients. TB patients belonging to Islam/Christian by religion were 5.90 times more likely to have HIV; Hindu TB patients were 2.27 times more likely to have HIV in comparison to Buddhist TB patients. Occupation of the TB patients and prevalence of HIV was also found significantly associated in this study. TB patients who are labourer; who are housewives were more likely to have HIV. However,studies conducted in China and Nigeria found no any significant relationship between occupation of 
Prevalence of Human Immunodeficiency Viruses Infection among Tuberculosis

TB patients and prevalence of HIV. ${ }^{6,15}$ In this study, ever married TB patients were 1.5 times more likely to have HIV than unmarried TB patients. However, this study couldn't find anystatistically significantrelation between prevalence of HIV and marital status of TB patients. Similar studies conducted in China, Nigeriaalso couldn't establish marital status as a significant predictor for increased risk of HIV among TB patients. ${ }^{6,15}$ Similarly, this study couldn't find any significant association between prevalence of HIV and literacy status of TB patients. Finding is similar to a study conducted in Nigeria. ${ }^{15}$ However the prevalence of HIV was slightly higher among illiterate TB patients than literate.

This study couldn't escape out of limitations. This study was conducted among six selected sentinel sites which couldn't cover all the TB cases notified during the study period as well as lacks adequate geographical representation. Similarly, patients receiving TB diagnosis, treatment and care services from the private sector were missed by this study. Information regarding important predictors for TB and HIV like smoking habit, alcohol consumption, diabetic status was missed in this study, which could have otherwise explored additional evidences to strengthen TB-HIV co-infection program in Nepal.

\section{CONCLUSIONS}

Prevalence of HIV among TB patients has increased gradually in Nepal. TB patient characteristics like age, caste/ethnicity, religion and occupation were found significantly associated with theprevalence of HIV. Hence, information on the availability of diagnostic and treatment services as well as access to HIV prevention, diagnosis and treatment services need to be increased in these sub-groups of the population. Similarly, interventions like universal HIV testing among TB patients, TB/HIVcollaborative activities are necessary to scale up across the country.

\section{ACKNOWLEDGEMENT}

We would like to remember all the Provincial TB Coordinators (Barsha Thapa, Bimal Subedi, Sailesh Bhujel, Bharati KC, Diwas Acharya, Rajesh Sah) for their support throughout the study period. We express our deep gratitude to all the sentinel sites for conducting this study on time. Similarly, we would also like to thank all the laboratory technicians, survey coordinator and counsellor for their support during the study period. At last, we would like to remember and thank all the respondents who gave their valuable time for interview.

\section{REFERENCES}

1. Global tuberculosisreport 2017. Geneva: World Health

Organization; 2017. [Full Text Link]

2. Annual report 2072/73 (2016) National Tuberculosis Program Nepal. Kathmandu: National Tuberculosis Center; 2017 March. [Full Text]

3. Surveillance of HIV infection among patients with tuberculosis in Nepal. Bhaktapur: National Tuberculosis Center; 2014.

4. National Consolidated Guideline for Treating and Preventing HIV in Nepal. Kathmandu:National Center for AIDS and STD Control; 2014. [Full Text Link]

5. Sah SK, Verma SC, Bhattarai R, Bhandari K, et al. Surveillance of HIV infection among patients with tuberculosis in Nepal. SAARC JTUBER LUNG DIS HIV/ AIDS. 2015; 12(1): 25-30. [Full Text Link]

6. Wang L, Liu W, Wang L, Wang Y, et al. HIV Prevalence among Pulmonary Tuberculosis Patients in Guangxi, China. J Acquir Immune DeficSyndr. 2011 Feb; 53(Suppl 1): S61-5. [Full Text Link]

7. Manjareeka M, Nanda S. Prevalence of HIV infection among tuberculosis patients in Eastern India. JInfect Public Health. 2013 Oct; 6(5): 358-362. [PubMed]

8. Hasnain J, Memon GN, Memon A, Channa AA, et al. Screening for HIV among tuberculosis patients: a crosssectional study in Sindh Pakistan. BMJ Open. 2012; 2(5): e001677. [Link]

9. Jain SK, Aggarwal JK, Rajpal S, Baveja U. Prevalence of HIV infection among tuberculosis patients in Delhi-A sentinel surveillance study. Indian J Tuberc. 2000; 47: 21 6. [Full Text Link]

10. Ahmad Z, Bhargava R, Pandey DK, Sharma K. HIV infection sero-prevalence in tuberculosis patients. Ind J Tub. 2003; 50(3): 151-4.[Full Text Link]

11. Raizada N, Chauhan LS, Khera A, Sokhey J, et al. HIV seroprevalence among tuberculosis patients in India, 2006-2007. PLoS One. 2008 Aug; 3(8): e2970. [Full Text Link]

12. Yang Z, Kong Y, Wilson F, Foxman B, et al. Identification of risk factors for extrapulmonary tuberculosis. Clinical infectious diseases. 2004 Jan; 38(2): 199-205. [Full Text]

13. Kyu HH, Maddison ER, Henry NJ, Mumford JE, et al. The global burden of tuberculosis: results from the Global Burden of Disease Study 2015. Lancet Infect Dis. 2018 Mar; 18(3): 261-84. [Full Text Link]

14. Factsheet 2: People infected with HIV since the start of the 
Prevalence of Human Immunodeficiency Viruses Infection among Tuberculosis

epidemic in Nepal. Kathmandu: National Centre for AIDS and STD Control; 2018. [Full Text Link]

15. Oladeinde BH, Olley $\mathrm{M}$, Imade OS, Onifade AA. Prevalence of HIV infection among patients with pulmonary tuberculosis in a rural tertiary hospital in Nigeria. Niger J Exp Clin Biosci. 2014;2(2):90-4. [Full Text Link] 